\title{
THE USE OF DICTOGLOSS TECHNIQUE IN TEACHING WRITING OF PROCEDURE TEXT
}

\author{
JAFTIYATUR ROHANIYAH \\ Universitas Islam Madura \\ javetien8@gmail.com \\ KHAIRATUN NISAK \\ IAIN Madura
}

\begin{abstract}
Writing is a skill which is consider as difficult skill in teaching learning process because it need an effort to collect ideas and words on the paper. Most of student said that writing process is very difficult and often make them lazy and bored to write and to make student motivated and enthusiastic to study the teachers probably have the strategy, method or a technique to teach their students and this research attempt to describe the Dictogloss technique that is implemented by the teacher in teaching writing of procedure text in the ninth grade of SMPI Bahrul-Huda sumber anyar. From this research, the researcher want to know the process of dictogloss technique and the advantage of that technique in writing material. In this research, the resercher use qualitative approach. Data collection procedures that used in this research are observation, interview, and documentation. The result show that implementation of Dictogloss technique that is implemented by the teacher in the class room is run well and teaching learning process is successful by using the technique. Students get progress to write than before and they get many vocabularies as guided writing, they also know how to arrange words to be sentence then write it to be one paragraph but in the other side the technique is need much time and sometimes it affect student in learning.
\end{abstract}

Keywords: Teaching writing, Dictogloss Technique, Procedure text

\section{A. INTRODUCTION}

In every school there are many lessons which are available for the students, one of the lessons is include an English subject. In studying an English subject need a more comprehension because English is not our native language so that the students may feel a difficulty in their learning especially in writing, because writing is a craft and a difficult one in which the students need struggle of the words on paper (Rebecca, Simon, 2001). Therefore, the teacher in every school must choose a certain or suitable technique in the teaching learning process which is suitable with the student's ability and suitable either the classroom situation or student's condition.

Teaching learning process will be efficiency if the techniques used by teacher are relevance and the material designed systematically (modul, 2014). If the strategy and technique are suitable with the student's ability, it will help them to get easy in learning English and to make the student success in learning the teacher should know the student's learning style, learning style of student can be said active if they work together (Sudarwan, 2010).

In teaching English especially in writing material sometimes the teacher feels difficult to make a student understand and feel difficult to make them pay attention to the teacher because sometimes the student feel bored with the teacher's strategies. Therefore, to teach writing material the teacher tries to use a suitable technique that there are many kinds of techniques which can be used by teacher in teaching writing. In this research the teacher uses Dictogloss technique in teaching writing. 


\section{VOL. 01 NO. 01, JUNE 2019}

Some people says that Dictogloss technique is similar with dictation technique where the Dictogloss technique is being a traditional dictation and only the name that is differentiate both of this technique but actually both of the technique exactly different. In dictation technique the teacher dictates by giving a text to the students than the students write down what the teacher says about the text given, it notices that they must write a text which is automatically same with the teacher and it can be only done and controlled by the teacher so that the students do not have an opportunity to work base on their own work and let them make a copy of the text that the teacher read only without doing any thinking that way it can be called as the teacher-centered in teaching learning process. So, it is different with Dictogloss technique where the teacher dictates a text to the students than they only listen to the teacher not write down as what the teacher says in which they only write down the key word and they work and discuss it in a group, in this process let them think base on their own then they identify and reconstruct the text in this process they find out what they do not know, and they find out what they need to know through the active learner and it can be called as the student-centered not only the teacher who become a center of knowing and getting a knowledge in teaching learning process.

There are many teachers who still use or implement dictation technique from yesterday until now. May a dictation technique which uses today and yesterday is being used to know the student understanding and comprehension but in long time ago the teacher used dictation technique only dictated about the lesson which was not written in the black board where the teacher just dictated them. In the other side a dictation who uses it can involve the student in learning because they do not have change to think and to learn because by themselves and sometime they fell that they do not have a self confidence and have a doubt about what they write is wrong with the teacher's dictation because indirectly they force to write same with the teacher. Everybody think of dictation as an "out mode done" teacher centered in writing activity with no real input from the student because of that a dictation has develop time in time and now become a new technique (traditional technique) which is called Dictogloss. The teacher ever use dictation technique in teaching writing but in using the technique sometimes one of the students make a noise by asking the other student while dictation process is done because they do not clear enough or may they lose concentration about what the teacher dictate or may they get trouble with their ear so that affect the other student. To overcome that problem the teacher uses the other technique where the teacher grouping the students and dictate about something than order the student to make a writing with their group about key word/the point of the text which is already given. So, indirectly the technique that is used by the teacher is called Dictogloss technique but the teacher unaware of what kind of a technique he uses. From the fact above, here, the researcher want to know: How does the teacher implement the Dictogloss technique in teaching writing of procedure text at the ninth grade of SMPI Bahrul-Huda Sumber Anyar? and What are the advantages and disadvantages of using the Dictogloss technique in teaching writing of procedure text at the ninth grade of SMPI Bahrul-Huda Sumber Anyar?

\section{Research approach}

In through of this research the researcher used qualitative approach to describe and analyze the data based on phenomenon. Qualitative approach is an inquiry approach useful for exploring and understanding a central phenomenon (Creswell, 2012). The researcher tried to observe the contradictory between the theories and the unusual fact (phenomenon) by analyzingtask aboutphrase and found a phenomenon in the subject of this research, then describe it by using written form. 


\section{VOL. 01 NO. 01, JUNE 2019}

And also the researcher uses descriptive research through this study. Descriptive research deals with data that are in form of words or pictures rather than numbers and statistics (Ary,1997). Descriptive research provides information about conditions, situations, and events that occur in the present (Neville,2005).

Qualitative approach is selected and chosen by the researcher as suitable research in analysing and describing the implementation of Dictogloss technique that is used by the teacher in teaching writing of procedure text at the ninth grade of SMPI Bahrul-Huda Sumber Anyar.

They are subject and object of research; Subject of research in this study is the ninth grade of SMPI BahrulHuda Sumber Anyar, while the object of research in this study is the Students writing of procedure text by using the Dictogloss technique and for Data collection procedures that used in this research are observation, interview, and documentation. The researcher does the following steps:

\section{1) Observation}

This is the first step that researcher does to collect the data. It is one kind of technique that is used by researcher to know or investigate the phenomenon. The researcher applies this technique to observe the students'mastery in noun phrase, in order that the researcher gets the real information of the phenomenon. In qualitative research, there are two kinds of observation, non-participant observation, and participant observation (Creswell,2012). The detail explanations are follows:

a. Participant Observation

A participant observer is an observational role adopted by researchers when they take part in activities in the setting they observe. In this observation, the researcher acts as participant who is involved in participants' activity and experiences the same thing like them.

b. Non-Participant Observation

Non-participant observer is an observer who visits a site and records notes without becoming involved in the activities of the participants. In this observation, the researcher acts as non-participant who completely hides his identity and not involved in participants' activity. To gather data, he may use hidden camera placed where he wants to gather data about. She may also does not participate actively during the research conduct. The research will apply non-participant observation, where she will observe SMPI Bahrul-Huda Sumber Anyar without being included in the same situation as them. In this case, the researcher observes the student writing of procedure text by using the Dictogloss technique.

\section{2) Interview}

Interview is one of technique in collecting the data. It provides information that can not obtained through observation. Lexy gave the defination of interview that interview is a 
meeting of two persons to exchange information and idea through question and responses, resulting in communication and joint construction of meaning about particular topic (Meleong,2014).

Interview can also be used to collect data on the factual information especially, information of students writing of procedure text by using the Dictogloss technique. There are two kinds to do an interview :

a) Structured interview

In structured interview, the researcher must prepare some questions. Then researcher already gives the questions to respondents.

Structured interview has a schedule to do an interview in order that the researcher gets the information as well as possible and relevant with the research.

b) Unstructured interview

Unstructured interview are more flexible and open although the research purposes given the question asked, content, sequence, and their wording are entirely in the hands of interview. While, unstructured interview is an interview in which the researcher does not make any preparation before it.

In this research, the researcher uses structured interview because the researcher has already made a list of questions and he has schedule to do an interview.The researcher did interview to the teacher and the students at ninth grade of SMPI Bahrul-Huda Sumber Anyar. The researcher used structured interview to get the data about students eriting of procedure text by using Dictogloss technique.

\section{3) Documentation}

Documentation is used as evidence or proof That definition is almost the same as Creswell's statement who stated that Documentsconsist of public and private records that qualitative researchers obtain about a site orparticipants in a study, and they can include newspapers, minutes of meetings, personal journals, and letters ' Documentation is used as sources of data which is formed as written data that is needed by researcher to prove that the data is really valid. The researcher also will take students'task to check and find out the students writing procedure text noun phrase at ninth grade students of junior high school level.

Data analysis is one of step in the research. The Data can be analyzed when all of the data are collected by some collecting data techniques. So after we finished all data collected, then the researcher will analyze the data.In analyzing data, the researcher uses analysis descriptive qualitative research, some data that used in analysis descriptive such as students' writing of procedure technique used Dictogloss technique, students'writing activities and writing treatment that teacher applies during teaching learning process.

This term is a very crucial part because the result of this research must be checked in order to avoid invalid data and also to ensure that this data is reliable and valid, In Creswell book stated that Data validity means researcher determines the accuracy or credibility of the findings through strategies such as member checking or triangulation (2012). And to make sure that this data is really valid, the researcher has used it. 
VOL. 01 NO. 01, JUNE 2019

\section{Triangulation of Data}

Triangulation is the process of corroborating evidences from different individuals, types of data, or methods of data collection indescriptions and themes in qualitative approach. The researcher also tried to check the data in students writing task of procedure text and check their writing result. There are 3 kinds of triangulation. Triangulation of Data Source, triangulation of data technique and triangulation of time.

\section{Member Checking}

Member checking is the process of the researcher to ask one or more participants to check the accuracy of data. To measure that the data is valid and accurate with what researcher asks to participant.

\section{Research Steps}

The researcher used some steps that are done by researcher. They are:

a. Pre-research

1) Determining the problem of focus

2) Making the title of research

3) Determining the context and focus of research

4) Making a thesis proposal and arranging the researcher licensing

b. The process of research

1) The researcher began by observing, interviewing and documenting for students' writing of procedure text

2) The researcher checked the students' writing result to make sure how deep their understanding and comprehension in writing.

3) After collecting the data, the researcher analyzed again the data obtaining to gain validity data

c. The process of data analysis

In this step, the researcher analyzed the data which were gotten from observation, interview, and documentation. Then the researcher displayed or classified the data based on focus of study.

\section{FINDINGS AND DISCUSSION}

The researcher took data from inside and outside of class. Inside the class is the students' activity on English subject. The ninth grade students of SMPI Bahrul-Huda Sumber Anyar Junior high school that containing of 28 students. 


\section{VOL. 01 NO. 01, JUNE 2019}

Meanwhile this section will be began from descriptions. The descriptions are: the teacher implement the Dictogloss technique in teaching writing of procedure text at the ninth grade and the advantages and disadvantages of the technique used.

To know the students' mastery, the researcher takes some ways of the field as follows:

1) Direct interview with the teacher of English subject in SMPI Bahrul-Huda Sumber Anyar.

2) Direct interview with the ninth grade students of SMPI Bahrul-Huda Sumber Anyar

By those ways, the researcher can describe and analyze the students' writing result by using dictogloss technique and the advantages and disadvantage of the technique of student in learning writing of procedure text The Implementation of Dictogloss Technique in the first meeting showed that the student writing did not satisfy because 18 students did not understand and could not write well and there are many mistakes in their writing in the form of content and grammar. While in the second meeting showed that the student's writing result got satisfied because there were only 6 students who get a mistake and bad in writing. It show that the result of this research about implementation of Dictogloss technique is more success than the first meeting and shows that the Dictogloss technique is a good technique that help student to write easily.

In implementing Dictogloss technique in teaching writing make students easy to compose and arrange many words in a group, involve them being active in learning process, increase their confident in writing and help them in knowing or getting much vocabularies as guided writing and student also can give their ideas and get knowledge from the teacher correction on their writing task. While in the other sides by using Dictogloss technique is needed much time and will make student feel bored and it considers as boring process and students does not have a chance to work base on their own work. In the reconstruction process also makes the class crowded so that it affects the class room management in teaching learning process.

Base on the result above, it was found that the implementation of Dictogloss technique had successfully help student easy to write about procedure text and they get progress in how they collect many words to start writing where it is gotten from the technique they used.

\section{CONCLUSION}

After analyzing the data, it was found that student writing result is satisfied and students get progress in writing that is looking from the student writing result that got satisfied because there were only 6 students who get a mistake and bad in writing. It show that the result of this research about implementation of Dictogloss technique is more success than the first meeting and shows that the Dictogloss technique is a good technique that help student to write easily. From the data, it can be concluded that teaching procedure text by using Dictogloss technique helps the students to increase their writing of procedure text.

\section{References}

Stott, Rebecca. 2001. Writing with style, London: library of congress cataloging.

Tim fasilitator. 2014. ModuL. Surabaya; Surabaya press.

Danim, Sudarwan. 2010. Psikologi Pendidikan Dalam perspektif baru. Bandung: Alfabeta.

Ary, Donald and Friends. 1997. In Introduction to Research in Education . New York: Holt Rine Heart and Wiston. 
VOL. 01 NO. 01, JUNE 2019

Postlethwaite, Neville. 2005. Educational Research: Some Basic Concepts And Terminology. Paris:UNESCO.

Creswell, John. 2012. Educational research fourth edition. Boston: Pearson

Education Inc.

Maleong, lexi. 2014. Metodelogi Penelitian Kualitatif Edisi Revisi. Bandung: Remaja Rosda Karya.

Creswell, John. 2012. Educational research (planning, conducting andevaluating quantitative and qualitative research, Bustonpress.

Sugiono. 2010. Metode penelitian kuantitatif kualitatif dan R \& D. Bandung : Alfabeta. 